revista ANTHROPOLÓGICAS

Ano 24, 31(1): 105-140, 2020

\title{
'Uma Área de Pastagem Ela Não Tem a Qualidade de Erva Medicinal': entre saber e poder, território e territorialidade Tembé
}

\author{
Vanderlúcia da Silva Ponte \\ Benedito Emílio da Silva Ribeiro ${ }^{\mathrm{b}}$ \\ Antonio Sarmento dos Santos ${ }^{c}$ \\ Lourdes de Vasconcelos Bentes ${ }^{\mathrm{d}}$
}

\begin{abstract}
No artigo, analisamos as dinâmicas territoriais entre os Tenetehar-Tembé, suas relações com os temas da saúde e da transmissão dos saberes sobre o uso de 'ervas medicinais'. Por meio de etnografia e da história oral, constatamos que as práticas de cura do povo Tembé delimitam elementos de resistência e reexistência, que acionam a identidade e processo de territorialidade, sobretudo quando em tensão com os modelos ocidentais de biomedicina implantados pelo Subsistema de Saúde Indígena nas aldeias. Assim, verificamos que o tema da saúde se constitui em um importante recurso político deste grupo, dado seu teor estratégico e justificador para fortalecer a defesa de seu território e de sua 'cultura'.

Saberes, Saúde, Poder, Território, Territorialidade, Indianidade Tembé.
\end{abstract}

O objetivo do artigo é analisar as dinâmicas territoriais entre os Tenetehar-Tembé por meio da transmissão dos saberes sobre as 'ervas

a Professora Adjunta da Faculdade de História (UFPA - Campus de Bragança). Email: vantutorapa@gmail.com.

b Mestrando na Pós-graduação em Diversidade Sociocultural/Museu Paraense Emílio Goeldi. Pesquisador do GEIPAM (UFPA) Email: emiliosilvaribeiro20@gmail.com.

c Escola de Ensino Fundamental e Médio Félix Tembé-PA, Indígena da etnia Tembé. Email: pina.tembe@yahoo.com.

d Escola de Ensino Fundamental e Médio Félix Tembé-PA. Indígena da etnia Tapajó. Email: lourdesbentes@hotmail.com. 
medicinais' ${ }^{1}$ entre gerações. Os processos de saúde e doença, o tratamento e cura, são saberes ancestrais que detêm os chamados 'velhos', que, por meio de troca de conhecimentos, ensinam aos jovens Tembé como operar os elementos culturais e defender o território. A pesquisa foi realizada ao longo de dois anos, por meio do projeto Wá Zemukátuhaw: práticas terapêuticas, território e cultura ${ }^{3}$, entre 2015 e 2017.

Entendidos como elementos centrais nos processos de reivindicações, nas lutas em defesa da indianidade ${ }^{4}$ e do território Tembé, o tema da saúde indígena emerge como fio condutor que revela as dinâmicas políticas, cosmológicas, culturais, sócio-espaciais e ambientais erigidas por este povo, possibilitando desconstruir as imagens projetadas e cristalizadas no imaginário regional de que os Tembé 'não são mais índios', por já estarem muito misturados 5 . Esta imagem evoca uma visão negativa para a identidade Tembé e coloca em risco a garantia de usufruto de suas terras tradicionais. Assim, torna-se necessária uma constante afirmação da indianidade como recurso discursivo, característico da retórica Tembé e de suas práticas etnopolíticas.

Portanto, o artigo visa contribuir também com os debates antropológicos e interdisciplinares acerca dessas relações entre território e identidade indígenas, tratadas em artigos de Dominique Gallois (2004), Alfredo Wagner Berno de Almeida (2006) e na coletânea organizada por João Pacheco de Oliveira (2004a). Nossa proposta é trazer ao debate os desafios impostos aos Tenetehar-Tembé para defender seu território e identidade. A partir das vivências junto a este povo na Terra Indígena Alto Rio Guamá (TIARG) ${ }^{6}$, localizada na região nordeste do Estado do Pará, entre os rios Guamá e Gurupi, pudemos analisar as estratégias, seus agenciamentos e protagonismo na defesa dos direitos de existir como povo e produzir sua territorialidade.

$\bigcirc$ estudo em questão foi realizado em quatro aldeias da região do rio Guamá: Sede, Ytwuaçu, Pinawá e Ypyd'hô, e a metodologia aplicada consistiu no exercício etnográfico, orientado pelos ensinamentos de Roberto Cardoso de Oliveira (2000), que nos auxiliou no caráter constitutivo do olhar, ouvir e escrever, três etapas importantes 
no exercício de apreensão dos fenômenos sociais no trabalho de campo do antropólogo. Foram dois anos de pesquisa entre idas e vindas às aldeias, que foram intensificados após a pesquisa de doutorado de Vanderlúcia Ponte, uma das pesquisadoras deste estudo. Após sua defesa de tese, Piná Tembé e Lourdes Tapajós solicitaram-lhe apoio para fortalecer os saberes dos mais velhos, que se sentiam 'abandonados pelas lideranças', segundo afirmou Piná.

A pesquisa iniciou com uma reunião de planejamento com todos os velhos e velhas das aldeias, articulada por Piná Tembé e Lourdes Tapajós, sua esposa. Nesse planejamento, os Tembé decidiram quem e de que forma cada um deles contribuiria com a pesquisa. Piná e Lourdes ficaram responsáveis em conduzir as rodas de conversa, que ocorreram em 8 encontros, e o Sr. Pelé Tembé em acompanhar os jovens nos mapeamentos das 'ervas medicinais' e oficinas para o uso do GPS, ambos supervisionados por Marcus Vinícius da Costa Lima, geógrafo e pesquisador da Cartografia Social ${ }^{7}$. No total foram 4 oficinas com os jovens, e mais 5 meses de identificação nas matas e quintais das aldeias. Também foram feitas 16 entrevistas, usando-se o recurso audiovisual para registro das imagens e falas dos velhos e velhas, com o apoio da equipe do Grupo de Estudos dos Povos Indígenas 'Eneida Corrêa de Assis' (GEPI) ${ }^{8}$, durante um mês. As entrevistas seguiam um pequeno roteiro de forma a identificar as plantas e seus benefícios associados às doenças, o modo de fazer os 'remédios caseiros' e as memórias que as experiências suscitavam. A partir dessa pesquisa foi elaborada uma cartilha paradidática para uso nas escolas das aldeias.

A observação direta ao longo do trabalho de campo nas aldeias Tembé, nos fez entender que a categoria 'velho' não é demarcada pela idade, mas pela experiência no uso das 'ervas medicinais', nos rituais de cura e pelos 'segredos' dominados a respeito das matas, dos rios, e dos seres espirituais (Karuwaras) que interagem e moram nesses espaços. Nas oficinas e no itinerário das matas, pudemos ver os inúmeros cuidados que determinam a relação entre as plantas e as Karuwaras ${ }^{9}$. 
Assim, conversar e pedir licença, antes de tocar ou subtrair a folha, o fruto ou a casca da árvore, pressupõe conhecê-la e a seu 'dono', tendo conhecimento de seus efeitos no corpo dos indivíduos. Nas rodas de conversa, acompanhando os jovens nas matas ou nas entrevistas e conversas informais com os 'velhos' e 'velhas', foi possível conhecer as práticas cotidianas, aqui incluídas as terapêuticas, e perceber determinados aspectos do modo de vida Tembé, bem como sua relação com as dinâmicas do território. Empregamos os recursos da história oral para acessar a memória dos Tembé e os conhecimentos tradicionais que se conectam a ela.

Desta maneira, por meio do projeto pudemos ouvir as narrativas produzidas ao longo dos percursos do mapeamento, das 4 oficinas, 16 entrevistas e 8 rodas de conversa coordenadas por Piná Tembé e Lourdes Tapajós, identificando e escrevendo as histórias contadas pelos velhos e velhas sobre o uso das plantas e seus processos de cura, itinerários e memórias vividas a partir das sociabilidades que esses saberes produziram, e produzem. O registro, entretanto, dessas memórias não se deu unicamente para compor os entendimentos das categorias nativas e seus sentidos, mas para um processo de reexistência Tembé em curso, já que seus saberes passaram a ser enormemente afetados com a introdução dos medicamentos pelas equipes multiprofissionais de saúde dos Distritos Sanitários Especiais Indígenas (DSEI).

Realizamos as entrevistas semiestruturadas e conversas abertas e informais com caciques, parteiras, pajés, 'erveiras' e 'raizeiros' ${ }^{10}$, jovens das escolas e lideranças Tembé. Esses depoimentos devem ser desnaturalizados e problematizados enquanto fontes históricas, tendo em vista a intencionalidade de sua produção (Albert 2015). Ao longo da análise qualitativa dos dados, enfatiza a autora, é preciso perceber os vários sentidos que o dizer do entrevistado carrega no relato, as interpretações dadas aos eventos, e as formas utilizadas para expressar uma ideia ou contar sobre seu saber. $\mathrm{O}$ uso destes aportes metodológicos permitiu-nos uma análise aprofundada sobre as experiências e relações cotidianas dos Tenetehar-Tembé do Guamá, que trazem à 
tona parte da complexidade cosmológica deste grupo relacionada ao território e aos saberes tradicionais dos 'velhos'.

Compreendemos, ainda, certa ruptura entre pesquisador e pesquisado, pois foram os próprios Tembé quem agenciaram o método de pesquisa, ao definirem e articularem os agentes sociais e os processos que conduziram a pesquisa e o itinerário dos pesquisadores no decorrer do estudo, uma vez que para os povos indígenas: "sua organização política e forma de agir compõem um cenário estratégico e de mobilização em que os antropólogos podem ser um instrumento eficiente para acessar direitos na luta pela cidadania ou recursos" (Oliveira 2004b:19). No caso dos Tembé, eles (pesquisadores também) serviram para fortalecer seus saberes e defender a territorialidade.

Assim, ao longo do artigo, demostraremos, inicialmente, os conflitos, as resistências e os processos que incidiram na ocupação do território Tembé, o que possibilitou em nova reorganização interna e diferentes formas de defesa da territorialidade. No segundo momento, mostraremos como o tema da saúde e a implantação do Subsistema de Saúde Indígena acionaram a memória e as novas modalidades de organização, intensificando as práticas tradicionais e os saberes dos velhos, o que fortaleceu ainda mais a indianidade Tembé.

\section{Conflitos, resistências e relações de poder na defesa do território}

Os Tenetehar constituem um povo da família linguística TupiGuarani, sendo denominados por naturalistas e viajantes de Tembé e Guajajara. Os dois grupos, no entanto, têm história de contato diferentes e se consideram povos com unidades socioculturais autônomas. Nos relatos mitológicos, os Tenetehar acreditam serem constituídos de humanidade perfeita: 'gente verdadeira', que no sentido nativo expressa povo que detém profundo conhecimento da mata e dos seres sobrenaturais (Gomes 2002:47). Nos processos de contato, eles foram diferenciados em dois grupos, em virtude de sua localização geográfica: os que se fixaram no Maranhão foram chamados Guajajara; e os que passaram a habitar no Pará, Tembé. 
Quanto aos Tenetehar-Tembé, embora tenham sido agrupados em um único grupo, é possível verificar diferenciações marcantes entre aldeias distintas. Seus principais conjuntos de aldeias localizam-se próximos as margens dos rios da região nordeste do estado do Pará: no Gurupi, no Guamá e no Acará, além daquelas localizadas em Jeju e Areal, no município de Santa Maria do Pará. A história Tembé é fortemente marcada por uma série de conflitos e interdições por parte de diferentes agentes estatais e não estatais. E, em igual proporção, por resistências e assíduo agenciamento para defender sua unidade sócio-política e cultural. Com relação aos Tembé, sobretudo aqueles do Guamá (foco deste artigo), a maioria dos documentos históricos e relatórios encontrados na FUNAI, bem como grande parte da literatura antropológica, referem-se a esse povo como fortemente miscigenado, já muito integrado à sociedade nacional e vivendo maritalmente com negros e brancos.

Em sua dissertação de mestrado, Sara Alonso (1996) analisou as narrativas que versam sobre a indianidade Tembé do Guamá e as formas de (re)construção dos elementos culturais e identitários desse grupo. Em sua interpretação, esse grupo vivia o que a autora chamou de 'reorganização-revolução', o qual instituiu uma ressignificação da identidade através da organização política e controle territorial. Envoltos na narrativa dos chamados 'índios misturados', assinalou a autora, os Tembé do Guamá iniciaram uma verdadeira viagem de conexão com seu passado, indo buscar entre aqueles do Gurupi elementos que para os agentes externos eram considerados 'autênticos' da identidade Tembé.

Este foi um processo que, incentivado pelo Chefe de Posto da época, Dílson Marinho, criou entre os Tembé uma nova dinâmica política e social no conjunto das aldeias do Guamá e Gurupi, uma vez que a ameaça de perda do território era intensa devido as invasões da TIARG por fazendeiros e madeireiros. Influenciados pelas novas diretrizes constitucionais, que apregoavam, em seus ditames, os princípios do pluralismo étnico, o reconhecimento da autodeterminação 
dos povos e a salvaguarda das terras indígenas, os agentes da FUNAI buscavam fortalecer e garantir a permanência do povo Tembé na Terra indígena, renomeando as aldeias com os nomes na língua tupi, criando as 'missões'11 e as Assembleias de Velhos.

O dinamismo desse novo momento fez os Tembé perceberem que havia uma certa manipulação, por parte dos agentes da FUNAI, de modo a mantê-los sob sua tutela. Com o apoio do Conselho Indigenista Missionário (CIMI) e a participação nas Assembleias de Velhos, nos momentos que antecederam a promulgação da Constituição de 1988, os Tembé vivenciaram diversas experiências junto de outros povos acerca da defesa dos territórios indígenas. Mas, conscientes de que a TIARG não era somente um lugar para morar e viver, os Tembé começaram um longo processo de organização política, estabelecendo suas próprias regras de controle da indianidade.

Abandonando os ditames autoritários do então chefe de posto Dílson Marinho, enfatiza Sara Alonso, os Tembé do Guamá solicitaram apoio aos Tembé do Gurupi, e trocaram os nomes das aldeias, que haviam sido nomeadas com nomes tupi, mas de origem Wajãpi. Também proibiram os casamentos com não indígenas, interditaram a entrada de não indígenas dentro da TIARG, e iniciaram um processo de ocupação efetiva do território floresta a dentro. Isso implicava, de maneira prática, na integridade de seu território étnico, pois culturalmente os Tembé tinham uma circulação muito intensa entre o Pará e o Maranhão, por meio dos rios Capim, Guamá e Gurupi.

Com a criação da Reserva ${ }^{12}$ Indígena Alto Rio Guamá (RIARG), em 1945, pelo interventor federal Magalhães Barata, essa circulação foi impedida e os Tembé tiveram que viver confinados em uma área territorial de 279.897,70 ha. Ainda que houvesse muita vigilância e controle sobre essa circulação por parte dos agentes do Serviço de Proteção ao Índios (SPI), os Tembé continuavam a interagir com outros espaços de forte ligação simbólica e cultural para eles e, por essa razão, a fixação na 'reserva' era problemática, enquanto ressignificavam aquele território delimitado. 
As disputas fundiárias no nordeste paraense são outro ponto importante nesse processo, uma vez que essa região corresponde a uma das primeiras fronteiras de expansão na Amazônia, com incentivos para colonização e desenvolvimento agrícola desde o século XVIII (Velho 2009). Porém, verificamos que no século XX esses conflitos em torno da posse e usufruto de terras se intensificaram ao passo que a Amazônia se tornou palco das ações desenvolvimentistas do Estado brasileiro, vista como 'vazio demográfico' e fonte inesgotável de recursos a serem explorados para o 'progresso da nação', e do capital. Assim, os territórios de povos indígenas, comunidades negras rurais e camponeses tradicionais passaram a sofrer forte pressão desses setores da sociedade que buscavam transformar as paisagens de floresta em áreas desmatadas propícias para pastagens, zonas monocultoras, garimpos e exploração de madeira.

No caso dos Tembé, as invasões eram constantes desde a década de 1940. E o fato de não serem mais reconhecidos como indígenas 'puros', e em franco processo de integração na sociedade envolvente, foi fortemente empregado como retórica dos invasores para justificar a exploração dos recursos naturais e o esbulho territorial. Isso dava margem para a intensificação dos processos de invasão e ocupação de suas terras por parte de posseiros, fazendeiros, madeireiros, camponeses, muitas vezes, apoiados pelos governos locais e federal, com suas claras necessidades de expansão econômica na região. Segundo Noêmia Salles (1999), a partir da década de 1960 e ao longo das décadas de 1970 e 1980, as políticas que incentivavam novas frentes pioneiras de penetração e ocupação de 'espaços vazios' no nordeste do Estado do Pará, trouxeram um impacto muito acentuado sobre o território da então 'reserva', afetando os povos que nela habitavam: os Ka'apor, os Timbira, os Awá-Guajá e, sobretudo, os Tembé ${ }^{13}$.

Inúmeros conflitos que envolviam disputas pelo território Tembé são observados durante esse contexto. Conforme salienta Vanderlúcia Ponte (2014), três eventos são importantes para compreender esses conflitos fundiários na região envolvendo os Tembé: o caso da fa- 
zenda de Mejer Kabacznik; o caso das glebas da CIDAPAR; e o caso envolvendo a denominada 'estrada' das empresas Marajoara e Rosa Madeireira. Esses três episódios se relacionam a grandes empreendimentos de ordem privada, apoiados pelos poderes locais, com propriedades de terra que incidiram, e acabaram se sobrepondo, sobre o território Tembé. Isso desvela a delicada situação dos Tembé no curso da segunda metade do século XX.

Com a implementação dos direitos originários dos povos indígenas aos seus territórios tradicionais, previstos na Constituição Federal de 1988, conjuntamente a toda articulação política dos caciques e demais lideranças Tembé, foi possível garantir a homologação da Terra Indígena Alto Rio Guamá por meio do Decreto N. ${ }^{\circ}$ 011. de 4 de outubro em 1993. Com isto, um novo contexto de luta pela defesa do território teve início, já que a homologação paradoxalmente não representou a plena proteção daquelas terras pelo governo federal, pois determinados segmentos da sociedade não indígena continuaram exercendo pressões sobre a TIARG, impondo uma constante ameaça ao povo Tembé.

Assim, em um cenário marcado por um longo e árduo processo de defesa da posse efetiva da terra, os Tembé do Guamá e do Gurupi consolidaram alianças e parcerias no intuito de resguardar seu território ancestral, criando e articulando novas condições estratégicas para remediar os conflitos e os riscos iminentes de perda da integridade da TIARG. O CIMI, o Ministério Público, a própria FUNAI, mas também o mandato do deputado Edmilson Rodrigues, foram parcerias fundamentais dos Tembé para a recuperação e proteção do território. Ao nos referirmos ao território Tembé, estamos expressando os processos de disputas e de poder que engendraram a ocupação e o uso desse espaço, mas também os aspectos simbólicos que as experiências vividas foram ali dando sentido e significado a esse povo. Trataremos com maior profundidade o assunto mais adiante.

Entre os Tembé do Guamá, cujas aldeias se dispõem ao longo das margens deste rio, observamos que um dos recursos estratégicos 
utilizados para a defesa de seu território consiste em acionar a memória e os conhecimentos tradicionais dos mais velhos para evocar a ancestralidade da ocupação das terras e (re)ativar sua territorialidade. A criação da 'reserva indígena', em 1945, possibilitou o confinamento dos Tembé a uma área restrita, tendo que adaptarem-se longe de suas 'velhas' aldeias. Nucleados em torno dos postos indígenas da época, com o passar do tempo os Tembé foram criando novas aldeias naquele espaço, para o qual conferiam novos significados, distinto daquele esperado pelo órgão indigenista. Pouco a pouco, pelas suas experiências e conflitos no processo de homologação, os Tembé vão transformando a terra da reserva em território, lugar de memória, de afeto, vivências e práticas.

Assim, com a homologação da TIARG, os processos de territorialização vão se dando neste novo espaço e em suas fronteiras: já que é lá, na terra indígena, que as disputas se acirram com os fazendeiros e posseiros, e também é lá, que alianças se constroem com o CIMI, o Ministério Público e a própria FUNAI, que hora é parceira, hora não é. Com isso, a emergência das novas territorialidades são acionadas e, por isso, a experiência dos mais velhos, seus saberes e práticas, os rituais, as festas, as pinturas, as cantorias, a língua são redinamizadas e acionadas. Um processo que permite aos Tembé fortalecer a indianidade e garantir a permanência no território.

Nesse sentido, podemos dizer que o território Tembé vai sendo recriado, à medida que as novas territorialidades vão sendo acionadas e os espaços sagrados, de conflitualidade e de práticas culturais, vão sendo demarcados (Raffestin 1993; Porto-Gonçalves 2008). Este entendimento se alinha às colocações de Paul Little (2002), que, ao analisar a diversidade fundiária no Brasil e dimensionar os territórios sociais de grupos tradicionais e seus fenômenos de territorialidade historicamente situados, nos chama atenção para:

"O fato de que um território surge diretamente das condutas de territorialidade de um grupo social, implica que qualquer território é um produto histórico de processos sociais e políticos. Para analisar 
o território de qualquer grupo, portanto, precisa-se de uma abordagem histórica que trata do contexto específico em que surgiu e dos contextos em que foi defendido e/ou reafirmado.

Outro aspecto fundamental da territorialidade humana é que ela tem uma multiplicidade de expressões, o que produz um leque muito amplo de tipos de territórios, cada um com suas particularidades socioculturais" (Little 2002:3-4).

Seguindo a linha de pensamento do autor, os processos de territorialidade constituem-se como fenômenos particulares, porém não exclusivos. Nessa perspectiva, ainda que tais processos sejam singulares para cada grupo social, a análise antropológica das territorialidades proposta pelo autor permite visualizar as potenciais similitudes do fenômeno entre distintos coletivos e "vincular essas semelhanças a suas reivindicações e lutas fundiárias e descobrir possíveis eixos de articulação social e política no contexto jurídico maior do Estado-nação brasileiro" (Little 2002:3).

Centrada nessa relação, compreendemos a territorialidade enquanto processo engendrado historicamente, ao passo que os grupos evocam lógicas nativas, ou 'tradicionais', para a ocupação do espaço e manejo dos recursos físicos e biológicos, enquanto expressão de sua organização social. Isto, por sua vez, demarca elementos identitários próprios e os contextos simbólicos nessa espacialidade territorializada, a qual se transforma em território étnico e se encontra em constante processo de (re)construção. Neste escopo, a memória possui um lugar de destaque enquanto mecanismo pelo qual são acionados os vínculos afetivos com a terra, seus sentimentos de pertencimento e a historicidade de sua ocupação. E através desse agenciamento da memória, os Tembé do Guamá passaram a reivindicar seu território e identidades.

Como já mencionado antes, a questão da 'mistura' foi fortemente utilizada como estratégia para desmerecer e diminuir a luta dos Tembé, e suas formas de organização sociopolítica e territorial. Porém, os Tembé mobilizam outras interpretações em torno disso, de modo a justificar e legitimar os processos de mudança e reafirmar o seu lugar político enquanto grupo etnicamente diferenciado. Os usos discursi- 
vos das representações e elementos culturais movimentam sentidos outros no processo de tradução das identidades, no complexo jogo das relações interétnicas (Hall 2014). Isso fica evidente na fala do Tembé Manoel Gomes:

Eles sempre dizem que somos misturado, eles comentam isso aí, nessa parte, mas agora não é só os Tembé daqui, é os Tembé todo, do Gurupi, do Tome-Açú, eles comentam isso também, eles se deitam em cima disso, aí, mas sempre o Piná diz assim: e ele foi numa reunião em Brasília, comentaram que o Tembé não era mais índio, porque era misturado. Aí, o Piná respondeu: "mas por que os Tembé não são mais Tembé, por que não fala a língua? Aí se você der um sorvete para um macaco prego e ele tomar, então ele deixou de ser macaco? No mato ele não come isso, mas aqui ele comeu sorvete. Daí ele deixou de ser macaco?". Os Tembé não largaram de ser Tembé porque ele não fala a língua. E é só por isso que eles se debruçam em cima disso, por isso que o menino [Bewãri] saiu daqui pra estudar no Gurupi para aprender a língua e nos ensinar de novo ${ }^{14}$.

Conforme enfatizado, os Tembé, de maneira geral, têm sido identificados como 'índios misturados', 'aculturados', sobretudo por que grande parte não é mais falante da língua Tenetehar. Essa negação da identidade étnica dos Tembé, principalmente no Guamá, está firmemente relacionada com a pressão econômica do capital global e dos núcleos urbanos nessa região do nordeste paraense. Assim, em um processo de negociação e invenção do outro e de sua cultura, conforme nos aponta o debate de Homi Bhabha (1998), a lógica de negociação cultural com a sociedade não indígena demarca, como é o caso da língua entre os Tembé, um dos sinais diacríticos para o reconhecimento da indianidade, sem que isso signifique uma ruptura total entre um mundo e outro, mas um processo dinâmico de afirmação da identidade.

Mas, como apontado na anedota contada por Piná, e reforçado nos debates de Eduardo Restrepo (2015), a identidade não pode ser circunstanciada por um único aspecto 'fundante', pois ela se apresenta de forma multifacetada e interseccional, incorporando vários sig- 
nos e significados que se justapõem nos processos de definição de suas diferenças, conforme recorte temporal e espacial focalizado. De acordo com o autor, as identidades são historicamente circunstanciadas e recortam as experiências coletivas ao longo do tempo, selecionando os aspectos fulcrais para a legitimidade de seus discursos e corroborando para sua fluidez e constante transformação. Ou seja, as identidades não são fixas e imutáveis, essencializadas em si, mas adquirem outras nuances e meandros a partir de implicações sócio-políticas e que são traduzidos em discursos que podem, ao mesmo tempo, se justapor ou contrastar entre si. Essas ambiguidades, porém, não representam uma fragilidade na construção das identidades de um certo grupo social, mas revelam sua potencialidade criativa e inovadora.

Portanto, as identidades se instituem nessas relações dialéticas e conflituosas, entre o plano local de vivências tradicionais e as teias do mundo capitalista globalizado, tomando como pano de fundo os arranjos históricos e os contextos sociopolíticos que são (re)construídos pelos sujeitos e suas memórias em disputa. Assim, a revitalização da língua entre os Tembé do Guamá é um elemento no jogo múltiplo das identidades étnicas e de suas alteridades. Ao pensar nesse processo, por exemplo, a retomada da língua entre os Tembé do Guamá busca reforçar sua indianidade, não apenas como forma de ceder aos discursos, mas, sobretudo, de reaproxima-los desse saber ancestral, e das experiências vividas com seus antepassados, que eles forçadamente foram proibidos de expressar por conta das políticas integracionistas do SPI e da FUNAI.

Em conversa com Piná, ele recorda como isso se deu: "meu pai contava que para não esquecer a língua, ele fugia para o mato e falava com os bichos, pois ele era proibido de falar na aldeia" ${ }^{15}$. Esse relato ajuda a entender a importância para os Tembé de retomar o passado, sobretudo a dinamização dos saberes, das práticas e sua relação com o território. Como salienta o linguista Hein van der Voort:

"[...] o conhecimento de um povo sobre seu território e a documentação disso, refletindo nomes de rios, acidentes geográficos e outros 
aspectos da paisagem, podem fornecer provas de apoio necessárias como material irrefutável da língua em questão para a reivindicação territorial de um povo. Em vários casos, a linguagem documentada pelos primeiros exploradores pode funcionar como evidência circunstancial de que tal povo sempre viveu em tal lugar. Com isso, até mesmo o estudo de uma língua indígena quase extinta pode ter grande valor para a sociedade" (Voort 2019:374).

Nesse sentido, as memórias dos 'velhos', seus saberes sobre as 'ervas medicinais' e o processo de mapeamento das plantas pelos mais jovens, constituem importantes estratégias de resistência dos Tembé na direção do fortalecimento de suas identidades e da emergência de novas territorialidades. E é no campo da saúde, suas disputas e tensões dentro das aldeias entre saber tradicional e biomédico, que melhor podemos visualizar as emergências dessas novas territorialidade. Pois, por meio desses saberes e práticas, vemos o território se ampliando e os Tembé retomando os lugares das antigas aldeias, as 'aldeias velhas' que ficaram de fora da TIARG na demarcação e são renomeadas e revividas em outros espaços. As idas para as cidades próximas, Capitão Poço e Santa Luzia, possibilitam essa 'reconexão' com os lugares tradicionais que passaram a compor estes municípios, o que também contribui para o redimensionamento da territorialidade. Além disso, essa ampliação do território Tembé também está ligada a espiritualidade manifestada nos espaços sagrados e nos rituais, nas danças, cantos, elementos que compõe sua cosmologia.

\section{Relações intergeracionais, saberes sobre as 'ervas medicinais' e dinamização da territorialidade Tembé}

A saúde foi outro campo importante para os Tembé, sobretudo para suas lideranças. Foi utilizada como ferramenta de articulação etnopolítica, que lhes permitiu ampliar sua inserção e visibilidade étnicas por meio dos debates em torno das políticas públicas voltadas para a saúde indígena. Em sua tese de doutoramento, assentada em três eixos analíticos que se acham intrinsicamente interligados entre os Tembé - saúde indígena, território e indianidade, Vanderlúcia Ponte 
(2014) elenca, como fio condutor, as práticas de saúde diferenciadas gestadas pelos Tembé a partir da criação e implantação do Subsistema de Saúde Indígena, em fins da década de 1990, e dos processos de descentralização dos DSEIs. Frente este contexto, os Tembé trataram de acionar recursos discursivos e construir práticas que se relacionavam com suas dinâmicas políticas, identitárias e territoriais, no intuito de valorizar seus conhecimentos tradicionais que passaram a se chocar com as políticas públicas de saúde aplicadas localmente pelo Distrito Sanitário Especial Indígena Guamá-Tocantins (DSEI-GUATOC).

Conforme aponta Rosane Lacerda (2013), o Subsistema de Saúde Indígena, implantado a partir de 1999 com a Lei n. ${ }^{\circ}$ 9.836, Lei Arouca, surgiu como uma tentativa de fortalecer a atenção sanitária diferenciada aos povos indígenas no Brasil que compreendesse seu sistema cosmológico, práticas xamânicas e itinerários terapêuticos. Essa premissa se configurava em um campo de debates críticos sobre os antigos modelos integracionistas direcionados aos povos indígenas, bem como as bases ideológicas neoliberais de assistência à saúde, e atendia uma demanda crescente dos movimentos indígenas decorrentes das garantias previstas na Constituição de 1988.

No entanto, o que aconteceu na prática foi algo bem diferente da letra da lei. A perspectiva eurocentrada, fortemente enraizada na medicina alopática, assim como em outros campos científicos, dificilmente admite a complexidade e sofisticação dos conhecimentos tradicionais indígenas, rechaçando-os ou inferiorizando-os em suas hierarquias de legitimidade do conhecimento (Santos 2009). Isso ocorre por conta das implicações universalizantes atribuídas ao modelo científico ocidental, decorrentes de seus rigores metodológicos de experimentação e bases teóricas construídas a partir destes (Cunha 2017). Esses rigores e bases teóricas não alcançam as diferentes perspectivas indígenas, que a partir de um sistema sociocósmico particular produzem o corpo, concebem a saúde e a doença interligando-os às práticas xamânicas, de forma que a natureza assume complexidade ontológica, sendo o território e as múltiplas territorialidades construídas e reconstruídas 
nessas relações com os outros - os espíritos - 'donos' das plantas, dos animais, dos rios e das matas.

Assim, a maioria dos profissionais dentro dos postos de saúde instalados nas aldeias ignorava e desqualificava os saberes tradicionais e buscava impor cada vez mais os conhecimentos médicos racionalizados e tecnicistas. Não levavam em consideração que a saúde, para os povos indígenas, ultrapassa as barreiras físicas do corpo e atinge um patamar denominado pelos Tembé de espiritual. Isso é constatado nos rituais xamânicos de cura, nos quais a aplicação dos remédios é sempre acompanhada por cantos e rezas, evocando os seres espirituais que auxiliam no reestabelecimento da saúde.

O Subsistema de Saúde Indígena foi criado para juntar com os conhecimentos com relação aos povos indígenas. Mostrar os conhecimentos tanto na área de prevenção como curativa. A gente mostrou que nós temos também os nossos técnicos. E as pessoas perguntavam nas nossas reuniões: "quem são os técnicos de vocês?" Os nossos técnicos são os raizeiros, as pessoas que conhecem as raízes; "quem são os enfermeiros de vocês?" Sempre foram as nossas parteiras; e "quem são os médicos de vocês?" Os nossos médicos sempre foram os pajés. O que é interessante é que o nosso médico trata da saúde espiritual e mental, e o branco só trata do corporal e mental, mas o espiritual a gente não vê. Muitas das doenças são espirituais. Então, a gente tentou juntar isso no Subsistema de Saúde Indígena, mas no momento da implementação isso foi esquecido. Então, o que nós pensamos? Se as nossas parteiras foram incentivadas a não fazer mais o parto porque o conhecimento acadêmico, técnico diz que é perigoso uma parteira puxar uma criança, porque pode quebrar o braço, uma clavícula, um pescoço, e se nós continuássemos essa prática, a parteira tinha que assinar documento se responsabilizando se tivesse algum erro. Então, isso intimida! [...] A questão da prevenção foi ignorada, porque o projeto do governo de integrar tudo, não deixa mais tempo para ti colocar uma roça, colocar uma macaxeira, fazer as tuas festas tradicionais. A prevenção nós dependemos da água, muitas das vezes, a maioria dos não indígenas pensa que a questão da água serve só para lavar, tomar banho, lavar roupa, lavar louça, mas não! Nós temos a parte espiritual, tem horário aqui, a criança não pode entrar no rio em qualquer horário, a mulher buchuda também não pode, não é? Tem os horários que não pode vir no rio, que é respeitado, não pode. ${ }^{16}$ 
No relato acima feito por Piná, fica evidente que a implantação de um sistema de saúde específico para atender aos povos indígenas trouxe impactos para o modo de vida destas populações, ao passo que os saberes indígenas sobre aspectos tradicionais relacionados aos cuidados de saúde foram sendo inferiorizados e suplantados em detrimento dos saberes científicos da medicina ocidental. No caso dos Tembé, esse conhecimento biomédico passou a ser tensionado aos saberes e práticas tradicionais de seus pajés, parteiras, 'erveiras', 'raizeiros' etc. Essas tensões e conflitos não significaram o abandono, a perda e o esquecimento dos conhecimentos sobre as práticas de cura e os processos terapêuticos de cuidado em saúde e doença para este povo.

Assim, os Tembé do Guamá, imersos nas práticas de resistência e reexistência em torno da defesa de seu território e das suas especificidades sociocósmicas, gestaram um projeto que visava levantar, mapear e analisar seus recursos culturais de valor terapêutico e seus processos sociocósmicos das práticas de cura, identificando os conhecedores e seus saberes tradicionais sobre os cuidados em saúde e doença. Em vigência entre 2015 e 2017, o projeto Wà Zemukátuhaw é criado, visando fortalecer os saberes tradicionais e a indianidade, como já frisamos na introdução deste artigo.

As iniciativas foram gestadas a partir das preocupações, que tinham os mais velhos das aldeias, com relação a transmissão de seus conhecimentos para as futuras gerações, desestimuladas em buscá-los por conta dos novos hábitos adquiridos com a inserção de elementos da vida moderna ocidentalizada. Além disso, igualmente despontam como respostas eficazes aos conflitos gerados por conta do Subsistema de Saúde Indígena e seus embates com o conhecimento tradicional indigena:

Quer ver outra coisa? "Olha! Não pode fazer esses remédios aí do mato! É perigoso! Porque tu podes fazer em quantidade e prejudicar o paciente. Então, esses remédios da cidade já vêm com a dose certa. Então, esses remédios do mato vocês pegam qualquer mato, coloca muita casca e pouca água”. Então, isso prejudicou muito a prática tradicional da saúde indígena. ${ }^{17}$ 
Nessas tensões com o Subsistema, frisadas por Piná, e os ditames alopáticos da medicina ocidental, os Tembé buscaram fortalecer seus saberes sobre as práticas tradicionais. Nas rodas de conversa, que ocorriam em espaços coletivos para garantir a transmissão dos conhecimentos, os 'velhos' iam recontando as histórias sobre as 'ervas medicinais', lembrando de receitas, modo de preparo, partes utilizadas nos remédios, usos e aplicações aprendidos por estes com seus pais, mães, avós ou outros membros familiares. Restituindo esses saberes ancestrais ensinados por seus antepassados, os 'velhos' foram identificando, nos quintais das casas e nos entornos das aldeias, as plantas e animais que possuíam valor xamânico e poderiam ser utilizados na administração dos remédios e curas. Isto demonstra a ligação desses saberes com as práticas e vivências cotidianas nas aldeias e as interações com o território e a terra, presente na memória dos 'velhos' e que se redinamizava com as ações do projeto.

Enquanto esses recursos eram levantados, os 'velhos' ensinavam aos mais jovens suas propriedades medicinais, as utilidades e efeitos decorrentes de sua ingestão, ou aplicação, conforme podemos observar no Quadro 1 (Anexo). Assim, inúmeras ervas compõem os itinerários de cura dos Tenetehar-Tembé no Guamá, e esses saberes são associados a determinados 'velhos'. Entre eles, identificamos os principais conhecedores durante as rodas de conversa: Kudã’i Tembé, professora de cultura da aldeia Sede; Edna Maria dos Santos, erveira e Agente Indígena de Saúde (AIS) da aldeia Sede; Pelé Tembé, cantor e AIS da aldeia Sede; Maria Oliveira da Conceição, erveira da aldeia Ytwuaçu; Tereza Horácio da Paixão, rezadeira da aldeia Sede; Maria do Socorro dos Santos, erveira da aldeia Sede; Maria Paulina, raizeira da aldeia Sede; e Francisca dos Santos Soares, pajé, parteira e AIS da aldeia Ytwuaçu.

Dentre estes, Dona Paulina possui um dos maiores repertórios de saberes sobre a administração das ervas e aplicação dos remédios. Ela conhece os usos xamânicos do abacaxi, arruda, banha de arraia, banha de curarú, banha de galinha, banha de jiboia, banha de porco, 
buruçu, camapu, canoinha, casulo de caba, catinga de mulata, caximguiua, cedro, cumê de tucura, hortelã grande, hortelãzinho, jatobá, mapá, mastruz, mortinha, nanin, pariri, primavera, quebra-pedra, sebo de holanda, sequiua, suador, tapioca do batatão. "A gente tem muito remédio caseiro, que a gente só lembra quando a pessoa está doente, ah! Tal coisa é bom! A gente vai lá e tira”. ${ }^{18}$

Junto a esta necessidade de valorizar os saberes, percebemos também um processo de fortalecimento e ampliação do território enquanto importante marcador cultural na afirmação da identidade Tembé. Ao se concretizar a identificação e mapeamento das diversas plantas utilizados para a transmissão dos saberes tradicionais relacionados à saúde, foi possível dimensionar os espaços indispensáveis, no interior da TIARG, para a sobrevivência étnica do grupo, tais como áreas sagradas e de práticas tradicionais. Isto justifica, portanto, a necessidade de preservação da unidade territorial e dos recursos naturais existentes na TIARG de modo a manter ativa aquilo que os Tembé concebem como cultura, e que é traduzida como 'cultura' com aspas (Cunha 2017) ao passo que eles mobilizam discursos em torno das 'ervas medicinais' e seus recursos terapêuticos ligados ao território. Conforme aponta o cacique Naldo Tembé:

A questão territorial e a questão da medicina, tudo a gente depende da floresta, uma área de pastagem não tem a qualidade de erva medicinal, ela tem um mato sem a mínima importância. A floresta em pé, ele tem a qualidade que nós necessitamos porque tem todo tipo de madeira. As pessoas dizem: "ah, a árvore madeireira!” Mas, às vezes, não sabem qual a importância que tem aquela árvore. Eles dizem: "a madeira serve para fazer uma casa”, mas para gente não. A casca dela, a fruta dela, a flor dela, tudo a gente necessita para fazer remédio. Por exemplo, a barbatimão, ela não dá em capoeira, é na mata, é na floresta e sem a floresta ela vai embora. Então, isso reforça porque nós queremos uma área grande $[. ..]{ }^{19}$

Esta fala reflete uma preocupação muito grande dos Tembé, ligada às estratégias de recuperação da TIARG. Como já frisado antes, as diversas invasões provocaram mudanças significativas na paisagem, 
uma vez que áreas de floresta primária foram transformadas em pastagens, cederam lugar para o campo e tornaram-se 'mato sem a mínima importância'. A fazenda de Mejer foi um dos principais focos dessas invasões e conflitos na TIARG. E em 2014, foi retomada pelos Tembé após ordem judicial, causando alguns impasses entre o grupo, pois há entre as lideranças os que querem permanecer com a fazenda, garantindo uma espécie de 'poupança' para a sobrevivência do grupo, mas há os que desejam o reflorestamento. Afinal, como frisado por Naldo: "tudo a gente depende da floresta". Nesse entendimento, (re)conhecer a floresta e, sobretudo as espécies medicinais, é importante para sustentar parte também de sua territorialidade em expansão hoje. As 'ervas medicinais', elencadas no mapeamento, são a demonstração desse desejo de permanecer expandido essa territorialidade.

Como podemos observar no Quadro 2 (Anexo), encontram-se relacionadas as plantas dispostas no território Tembé, trazendo à tona as categorias de organização espacial usada por estes. Para que fosse possível compilar esse quadro, os mais velhos identificaram as plantas indispensáveis aos Tembé, para evitar sua extinção, e garantir os remédios e banhos para os rituais de cura. Ao passo que os velhos identificavam as 'ervas medicinais', os jovens Tembé realizavam o mapeamento destas espécies etnobotânicas com o uso do GPS, pois tinham maior afinidade e facilidade para utilizar esta tecnologia. Ao longo desse processo, houve um importante alargamento das trocas intergeracionais de conhecimentos sobre os 'remédios caseiros' presentes no território Tembé, suscitando a valorização dos saberes tradicionais Tenetehar pelos segmentos mais jovens das aldeias Tembé, como enfatizado por Pelé Tembé:

Eu acredito que foi bom a criação desse projeto, porque os jovens fazendo esse trabalho com a gente, eles estão conhecendo, né... conhecendo sobre as ervas medicinais, aqueles remédios. Então, passaram a conhecer, já é um início para eles. Eu conversei com eles e eles disseram: "olha eu não sabia que esse remédio era bom para isso". [...] Então, eles tiveram uma experiência muito grande. Então, tem que continuar com esse trabalho para a gente passar 
para os outros. Acredito que mais importante vai ser ainda, porque a gente vai cuidar dessas ervas medicinais, que a gente tinha aí no terreiro, morria, que ia se acabar, porque a gente não cuidava, muitos não tinham esse conhecimento, só era o remédio da farmácia. Hoje, a gente já quer ampliar mais, né? Isso vai para frente. ${ }^{20}$

A memória foi ativada e criou-se novo dinamismo desses saberes, o que possibilitou seu compartilhamento com as gerações mais novas e o debate do tema nas escolas. Também foi possível ver como a territorialidade Tembé se estende e se amplia para outros lugares, para além das fronteiras jurídicas, pois são lugares de valor simbólico, marcados pela identidade coletiva e lugares da memória. As plantas identificadas nesse mapeamento cartográfico do território Tembé superam as fronteiras estabelecidas pelo Estado na região do rio Guamá.

As plantas e os animais, identificados como 'remédios' pelo uso de suas garrafadas, banhos, chás e banhas, não se encontram restritos ao espaço da TIARG, e a espiritualidade presente no uso das ervas, no preparo dos chás e banhos e nos processos de cura transcende qualquer lógica estatal e se liga diretamente ao território, aos lugares sagrados e de onde os elementos xamânicos são captados. Denota-se, por meio disso, que a qualidade e potencialidade xamânica das 'ervas medicinais', bem como dos demais elementos utilizados nos processos de saúde e doença, estão vinculados com a floresta e ao poder advindo deste espaço sociocósmico que ocupa a natureza na cosmologia Tembé, onde as Karuwaras habitam lugares que se sobrepõem nos vários estratos do cosmo desse povo (Coelho 2014).

Em sua cosmologia, o universo Tembé é percebido de forma integrada, interconectada: sociedade, cultura e natureza são dimensões que se complementam e se metamorfoseiam em muitas perspectivas, operando entre relações amistosas e conflituosas. Nesse entendimento, a saúde não se separa da educação, da política e, sobretudo, das dinâmicas do território, contribuindo com a delimitação de lugares carregados de sentido afetivo e simbólico, e que expressam laços identitários demarcados nas paisagens, nos corpos e nas memórias. Esta 
visão, porém, esbarrava com as disposições setorizadas e compartimentadas do mundo moderno-colonial e seu sistema racionalizado de conhecimentos. Isso gerava (e ainda gera) choques de percepções e saberes, que se intensificaram entre os Tembé a partir da maior inserção do Subsistema de Saúde Indígena nas aldeias.

Assim, os Tembé realizaram um movimento de complementaridade, não excludente, entre suas práticas de saúde tradicionais e as modalidades biomédicas de saúde. Por exemplo, durante a pesquisa em campo, um dos integrantes acabou acometido por uma febre muito forte e muita tremedeira durante a noite. Indagados pelo cacique Piná Tembé, da aldeia Ytwuaçu, comentamos que o mesmo havia ido ao igarapé mais cedo, um pouco após o horário do meio-dia. Acreditando que este havia sido 'flechado' pela mãe d'água (afetado por seus poderes espirituais), o cacique tratou de chamar a 'pajé' da aldeia, Dona Francisca, para verificar o que havia acontecido. Após examiná -lo com calma e precisão, Dona Francisca disse que aquela era 'doença de branco', que ela não podia fazer nada e que deveríamos levá-lo ao posto, para ser tratado com remédio apropriado. Essa pequena experiência revela como os universos indígena e não indígena ao mesmo tempo se imbricam e se distanciam, dando margens para antever as concepções construídas pelos Tembé no campo da saúde. Assim, o território Tembé - físico e simbólico - é o tempo todo dinamizado, recriado e transformado, já que as experiências externas vão possibilitando a esse povo ressignificá-las e introduzi-las em seus próprios contextos cosmológicos.

\section{Considerações Finais}

As colocações expostas permitem observar como os Tembé produzem e reproduzem sua 'cultura' e identidade, de forma dinâmica, nas interfaces com a sociedade envolvente e o mundo globalizado, bem como com outras populações tradicionais como quilombolas e ribeirinhos, demarcando seus sinais diacríticos. Como enfatizado por Frederick Barth (2000), essas fronteiras étnicas são socialmente 
construídas pelos grupos através de suas formas de organização e suas relações de sociabilidade, que demarcam diferenças por meio da alteridade e que igualmente ajudam a construir as representações sobre o território e suas fronteiras.

No conjunto de aldeias da região do Guamá, a organização política e a defesa da TIARG, largamente ameaçada e continuamente invadida, desencadeia no grupo um processo de defesa da autonomia e de forte sentimento de valorização da 'cultura' e de autoafirmação da indianidade, desde um contexto de assídua negação da mesma pelos órgãos indigenistas e demais agentes externos, mas também por um processo interno de valorização de seu mundo, seus sentidos e percepções de como compreendem os seres e suas agências na produção de seus corpos e de suas identidades. Nesse sentido, a defesa da territorialidade Tembé se expressa no fortalecimento de seus saberes, fonte inegável de se localizar no cosmo e se relacionar com os outros seres (humanos e não humanos), tangenciada por um processo de negociação cultural (Bhabha 1968) permanente, sem que seus sentidos cosmológicos sejam suplantados por outras lógicas. Assim, compreendemos que esse processo demarca uma ruptura com a tutela da FUNAI e inaugura a formação de um novo momento político de dinamização e valorização das práticas tradicionais, com a colaboração dos Tembé do Gurupi.

$\mathrm{Na}$ esteira desse mesmo processo, a Política de Saúde Indígena implantada por meio do Subsistema de Saúde Indígena e dos DSEIs reforçou ainda mais o processo de organização política Tembé, na medida em que impulsionou um movimento de resistência e reexistência por meio da afirmação dos saberes e práticas tradicionais, fortalecendo os aspectos positivos da indianidade. Os 'velhos' e as 'velhas' das aldeias, imbuídos de seus saberes tradicionais, tornaram-se agenciadores desse processo, já que, por meio da transmissão de seus conhecimentos para as futuras gerações, recriaram novas modalidades de territorialidade, acionando o uso das 'ervas medicinais' como recurso da memória para ampliar o território. 
Compreendemos, portanto, que o tema da saúde se constitui em um recurso justificador para fortalecer a luta pela legitimidade política dos Tembé, pelo reconhecimento de sua indianidade e pelo direito a viver em um território. Nesse sentido, a criação de uma outra territorialidade emerge em resposta aos processos de intervenção da sociedade nacional através do Subsistema de Saúde, na qual as fronteiras espaciais são encaradas de maneira fluida e porosa, extrapolando a espacialidade física da TIARG. Revelam a expansão das territorialidades à medida que os saberes tradicionais são acionados, praticados e tensionados pelos conhecimentos sanitários. Temos, então, um processo de retomada assídua da medicina tradicional enquanto forma de afirmação da indianidade Tembé, fortalecendo a participação dos 'velhos' e a transmissão e circulação dos saberes sobre as 'ervas medicinais' nas aldeias, sobretudo junto aos jovens.

\section{Notas:}

1 Categoria nativa utilizada pelos Tembé para referir-se ao conjunto de plantas e animais que possuem valores xamânicos, farmacológicos, e podem ser empregados para a fabricação tradicional de remédios (banhos, chás, garrafadas, emplastros etc.) administrados para as pessoas doentes em suas aldeias.

2 Categoria que, entre os Tembé, é empregada para referir-se aos detentores e conhecedores da cultura ancestral, sem necessariamente estar intimamente ligada a idade.

3 Projeto financiado pela Universidade Federal do Pará, por meio da Pró-Reitoria de Ensino de Graduação (PROEG) e pela Faculdade Integrada Brasil Amazônia (FIBRA). Surgiu da iniciativa dos velhos das aldeias que, com o apoio de Piná Tembé, solicitaram à pesquisadora Vanderlúcia Ponte colaboração para retomar as práticas de saúde por meio das 'ervas medicinais' e repassá-las às futuras gerações. O projeto teve como bolsista Benedito Emílio Ribeiro.

4 A categoria indianidade é empregada de acordo com a análise de Antônio Carlos de Souza Lima (1995), como um processo de afirmação identitária em oposição às políticas indigenistas que busca(va)m reduzir o indígena a uma indianidade mínima - processo de branqueamento -, por meio da introdução de práticas não indígenas e proibições de suas expressões culturais, integrando-os à sociedade dita nacional.

5 Pacheco de Oliveira (2004a) utiliza o termo 'índios misturados' para se contrapor à forma como os índios do Nordeste vivenciam suas lutas políticas e de reivin- 
dicação identitárias, propondo a termologia 'etnogênese' para se contrapor às ideias de índios 'remanescentes' ou 'resíduos de populações'. O conceito de 'etnogênese', para o autor, expressa a positividade do processo político vivido pelos índios do Nordeste.

6 A denominação TIARG difere de RIARG, que significa Reserva Indígena Alto Rio Guamá. Como explicado mais à frente no texto, a reserva foi criada em 1945 e estava relacionada ao sentido de confinamento, restrição da mobilidade indígena e gestão racional do território e seus recursos. Da mesma forma, o termo TIARG retrata uma ação imbuída de um contexto histórico, demarcado pelos movimentos sociais indígenas, que busca(va)m legitimar seus direitos às terras tradicionalmente ocupadas, direitos que são consagrados na Constituição de 1988.

7 Nova Cartografia Social da Amazônia é um projeto de autocartografia realizada pelos movimentos sociais, com o apoio de pesquisadores de diferentes universidades, coordenado pelo Dr. Alfredo Wagner de Almeida (UFAM) e pela Dra. Rosa Acevedo Marin (UFPA). O projeto objetiva visibilizar os processos de ocupação dos povos na Amazônia, identificando as territorialidades específicas, suas lutas e resistências. Os materiais produzidos servem como instrumento político em suas reivindicações por direitos.

8 Agradecemos o apoio do GEPI, em nome da Dra. Denise Machado Cardoso (UFPA), Roberta Pereira da Costa (in memoriam), Alexandra Borba e Cristiane Modesto do Nascimento.

9 Karuwara é uma categoria nativa que pode ser relacionada com alma ou sombra da pessoa. Para os Tembé, as karuwaras são os espíritos dos antepassados, plantas, animais, sementes ou parentes que já morreram, que podem agir no corpo dos indivíduos. Esses seres já foram pajé e têm muitos poderes podendo ocasionar doenças, cura e a morte dos indivíduos.

10 Os termos 'erveira' e 'raizeiro' são utilizados pelos Tembé para referirem-se aos seus especialistas no conhecimento e uso tradicional das plantas medicinais.

11 Forma de vigilância realizada de tempos em tempos na TI pelos guerreiros Tembé, para expulsar os posseiros invasores.

12 O termo 'reserva' teve um viés político e ideológico muito forte no início do século XX, e perdurou por muito tempo. A ideia de reserva servia para demarcar a ação estatal sobre os territórios indígenas, concebidos como em estado transitório, cuja prática do Estado se operaria por meio da proteção. Então, 'reserva' está relacionada à ideia de resquício, como algo criado artificialmente para estabelecer relação com o passado, atrelado a uma noção museológica de registro e preservação dessas culturas em 'vias de desaparecimento', para que sejam conhecidas pelas gerações futuras.

13 A RIARG foi criada para ser habitada por estes quatro povos indígenas. Porém, os Ka'apor e os Awá-Guajá permaneceram mais próximos de seus territórios tradicionais, no território maranhense, os quais hoje correspondem a Terra Indígena Alto Turiaçu, a Terra Indígena Awá, a Terra Indígena Caru e a Reserva Biológica do Gurupi. Estas, junto com a TIARG, formam um terreno contínuo, com grandes extensões de floresta preservada nessa região conhecida como Área de Endemismo Belém. 
14 Entrevista realizada por Vanderlúcia Ponte com Manoel Gomes, aldeia Pinawá, setembro de 2010.

15 Entrevista com Piná Tembé, aldeia Ytwuaçu, maio de 2016.

16 Entrevista com Piná Tembé, aldeia Ytwuaçu, setembro de 2015.

17 Entrevista com Piná Tembé, aldeia Ytwuaçu, setembro de 2015.

18 Entrevista com Maria Paulina, aldeia Sede, setembro de 2015.

19 Entrevista com Naldo Tembé, aldeia Sede, julho de 2016.

20 Entrevista com Pelé Tembé, aldeia Sede, setembro de 2015.

\section{Referências:}

ALBERTI, Verena. 2015. "Fontes orais: histórias dentro da História". In PINSKY, C. (ed.): Fontes históricas, pp. 155-202. São Paulo: Contexto.

ALMEIDA, Alfredo W. 2006. Terras de quilombo, terras indigenas, 'babaçuais livres', 'castanhais do povo', faxinais e fundos de pastos: terras tradicionalmente ocupadas. Manaus: PPGSCA-UFAM.

ALONSO, Sara. 1996. Os Tembé de Guamá: o processo de constituição da cultura e identidade Tembé. 1996. Dissertação de Mestrado. Rio de Janeiro: Museu Nacional-UFRJ.

BHABHA, Homi K. 1998. O local da cultura. Belo Horizonte: Editora da UFMG.

BARTH, Fredrik. 2000. "Os grupos étnicos e suas fronteiras". In LASK, T. (ed.): O guru, o iniciador e outras variações antropológicas, pp. 25-67. Rio de Janeiro: Contra Capa.

CARDOSO DE OLIVEIRA, Roberto. 2000. O trabalho do antropólogo. Brasília/ São Paulo: Paralelo 15/ UNESP.

COELHO, José R.. 2014. Cosmologia Tenetehara Tembé: (re)pensando narrativas, ritos e alteridade no Alto Rio Guamá - PA. Dissertação de Mestrado. Manaus: Universidade Federal do Amazonas.

CUNHA, Manuela C. 2017. Cultura com aspas e outros ensaios. São Paulo: Ubu Editora.

GALLOIS, Dominique T. 2004. "Terras ocupadas? Territórios? Territorialidades?". In RICARDO, F. (ed.): Terras Indígenas e Unidades de Conservação da natureza: o desafio das sobreposições, pp. 37-41. São Paulo: Instituto Socioambiental.

GOMES, Mércio P. 2002. O indio na história: o povo Tenetehara em busca da liberdade. Petrópolis: Vozes.

HALL, Stuart. 2014. Sin garantías: trayectorias y problemáticas en estudios culturales. Popayán: Universidad del Cauca, Fundación Envión.

LACERDA, Rosane F. 2013. "Por uma Perspectiva Descolonial dos Direitos Indígenas à Saúde”. Tempus: Actas de Saúde Coletiva, 7(4):37-50. 
LIMA, Antonio C. 1995. Um grande cerco de paz: poder tutelar, indianidade e formação do Estado no Brasil. Petrópolis: Vozes.

LITTLE, Paul E. 2002. Territórios Sociais e Povos Tradicionais no Brasil: por uma antropologia da territorialidade. Brasília: UNB-Série Antropologia.

OLIVEIRA, João P. (ed.). 2004a. A viagem da volta: etnicidade, política e reelaboração cultural no Nordeste indígena. Rio de Janeiro: Contra Capa Livraria /LACED. . 2004b. "Pluralizando tradições etnográficas: sobre um certo mal-estar na antropologia”. In LANGDON, E. \& GARNELO, L. (eds.): Saúde dos povos indígenas: reflexões sobre antropologia participativa, pp. 10-28. Rio de Janeiro: Contra Capa Livraria/ ABA.

PONTE, Vanderlúcia. 2014. Os Tenetehar-Tembé do Guamá e do Gurupi, povo verdadeiro!: "saúde diferenciada", território e indianidade na ação pública local. Tese de Doutorado. Belém: Universidade Federal do Pará.

PORTO-GONÇALVES, Carlos W. 2008. "De saberes e de territórios: diversidade e emancipação a partir da experiência latino-americana”. In CECEÑA, A. (ed.): De los saberes de la emancipación y de la dominación, pp. 37-52. Buenos Aires: CLACSO.

RAFFESTIN, Claude. 1993. Por uma geografia do poder. São Paulo: Ática.

RESTREPO, Eduardo. 2015. Intervenciones en teoría cultural. Popayán: Sello Editorial Universidad del Cauca.

SALES, Noêmia P. 1999. Pressão e resistência: os índios Tembé-Tenetehara do Alto Rio Guamá e a relação com o território. Belém: UNAMA.

SANTOS, Boaventura. 2009. "Para além do pensamento abissal: das linhas globais a uma ecologia de saberes". In SANTOS, B. \& MENESES, M. P. (eds.): Epistemologias do Sul, pp. 23-71. Coimbra: Almedina.

VELHO, Otavio. 2009. Capitalismo autoritário e campesinato: um estudo comparativo a partir da fronteira em movimento. Rio de Janeiro: Centro Edelstein de Pesquisas Sociais.

VOORT, Hein van der. 2019. "A relevância das línguas indígenas na biota amazônica”. In GALÚCIO, A. \& PRUDENTE, A. (eds.): Museu Goeldi: 150 anos de Ciência na Amazônia, pp. 351-385. Belém: Museu Paraense Emílio Goeldi. 
ANTHROPOLÓGICAS 31(1):105-140, 2020

Anexo:

Quadro 1: Relação de 'ervas medicinais’ utilizadas pelos Tembé do Guamá

\begin{tabular}{|c|c|c|}
\hline Nome Popular & Formas de uso & Parte \\
\hline Abacaxi & $\begin{array}{c}\text { Chá, junto ao Camapu e ao Quebra- } \\
\text { pedra }\end{array}$ & Fruta \\
\hline Alho & Chá, Xarope & Dente \\
\hline Alvavaca & Emplastro & Folha \\
\hline Amapá & $\begin{array}{l}\text { Fervido e tomado todos os dias no café } \\
\text { ou no mingau }\end{array}$ & Leite \\
\hline Anador & Chá & Folha \\
\hline Aroeira & Chá & Casca de pau \\
\hline Arruda & Banho, junto com a Catinga de Mulata & Folha \\
\hline Babosa & Cataplasma com o sumo & Folha \\
\hline Barbatimão & Garrafada, Chá & Casca de pau \\
\hline Bebecá & Banho & Folha \\
\hline Boldo & Chá & Folha \\
\hline Buruçu & Passar no corpo do doente & Casca de pau \\
\hline Café & Banho & Folha \\
\hline Cajuí & Chá & Casca de pau \\
\hline Camapu & $\begin{array}{c}\text { Chá, junto ao Abacaxi e ao Quebra- } \\
\text { pedra }\end{array}$ & Raiz \\
\hline Camilitana & Chá & Folha \\
\hline Canela & Banho feito com as folhas & Folha \\
\hline Canoinha & Emplasto & Leite \\
\hline Capim Santo & Chá & Folha \\
\hline Catinga de Mulata & Batido, Banhos & Folha \\
\hline
\end{tabular}


Ponte, Ribeiro, Santos \& Bentes: Uma Área de Pastagem

\begin{tabular}{|c|c|c|}
\hline Caximguiua & Chá e banho & $\begin{array}{c}\text { Casca de pau, } \\
\text { Leite }\end{array}$ \\
\hline Cedro & Passar no corpo do doente & Casca de pau \\
\hline Chicória & Chá & Raiz \\
\hline Cidreira & Chá & Folha \\
\hline Cipó Cabim & Banho para benzer & Cipó \\
\hline Copaíba & Tomar com leite & Óleo \\
\hline $\begin{array}{l}\text { Cordão de São } \\
\text { Francisco }\end{array}$ & Chá, Garrafada & - \\
\hline Coromina & Chá & Folha \\
\hline Cravina & - & Cipó \\
\hline Cuia & Banho & Folha \\
\hline Cumê de Tucura & Chá & Casca de pau \\
\hline Elixi -Parigórico & Chá & Folha \\
\hline Hortelã grande & Xarope, Chá & Folha \\
\hline Hortelãzinha & Chá com copaíba & Folha \\
\hline Hortelãzinho & Xarope, Chá & Folha \\
\hline Japana & Banho & Folha \\
\hline Jatobá & Chá & Casca de pau \\
\hline Lima & Chá & Folha \\
\hline Limão & $\begin{array}{l}\text { Partido, assado e misturado com alho } \\
\text { e mel }\end{array}$ & Folha \\
\hline Mastruz & Batido, Sumo & Folha \\
\hline Mortinha & Faz-se uma trouxinha & - \\
\hline Mucuracaá & Banho, Banho para benzer & Folha \\
\hline Nanin & Emplasto & Leite \\
\hline Pariri & Chá, Sumo & Folha \\
\hline Pau D'alho & Banho para benzer & Folha \\
\hline
\end{tabular}


ANTHROPOLÓGICAS 31(1):105-140, 2020

\begin{tabular}{|c|c|c|}
\hline Pimenta & $\begin{array}{c}\text { Amornar a folha e coloca sobre o local } \\
\text { afetado }\end{array}$ & Folha \\
\hline Pirarucu & Sumo e Chá & Folha \\
\hline Primavera & Utilizada junto ao Mastruz & Folha \\
\hline Quebra-pedra & Chá, junto ao Abacaxi e ao Camapu & Folha \\
\hline Ramona & - & Folha \\
\hline Sebo de Holanda & Ingerir misturado com banha de bicho & Sebo \\
\hline Sequiua & Emplasto & Leite \\
\hline Tapioca do & Ralada & - \\
\hline Batatão & Garrafada & Casca de pau \\
\hline Unha de Gato & Garrafada, Chá & Casca de pau \\
\hline Verônica & Passar no local & Folha \\
\hline Vinagreira Roxa & Banho & Folha \\
\hline Vindicá & - & Mel \\
\hline Abelha & Emplastro & Banha \\
\hline Anta & Emplastro & Banha de fígado \\
\hline Arraia & Pó em cima do umbigo & Casulo \\
\hline Caba & Emplastro & Banha \\
\hline Curarú & Massagear o peito da criança. & Banha \\
\hline Galinha & Preferencialmente, da galinha preta & \\
\hline Paca & - & \begin{tabular}{c} 
Fel \\
\hline
\end{tabular} \\
\hline
\end{tabular}

Fonte: Dados coletados em campo e sistematizados pelos autores. 
Ponte, Ribeiro, Santos \& Bentes: Uma Área de Pastagem

Quadro 02: Mapeamento das plantas medicinais no território Tembé

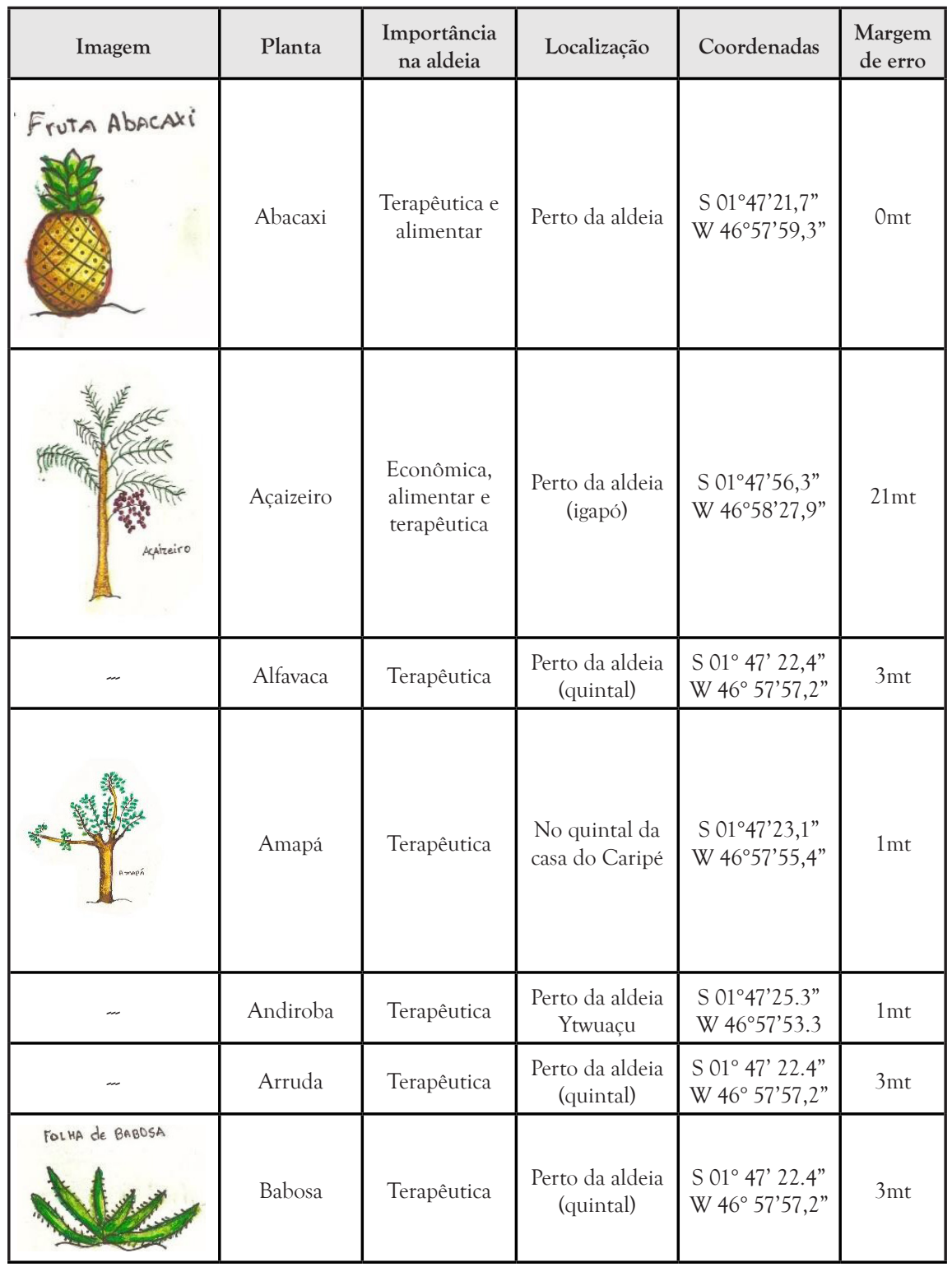




\begin{tabular}{|c|c|c|c|c|c|}
\hline- & Bananeira & Terapêutica & $\begin{array}{l}\text { No quintal da } \\
\text { casa da Tereza }\end{array}$ & $\begin{array}{l}\text { S } 01^{\circ} 48^{\prime} 013^{\prime \prime} \\
\text { W } 46^{\circ} 58^{\prime} 34.9^{\prime \prime}\end{array}$ & $0 \mathrm{mt}$ \\
\hline foLtiade & Boldo & Terapêutica & $\begin{array}{c}\text { No quintal da } \\
\text { casa de Dona } \\
\text { Socorro }\end{array}$ & $\begin{array}{l}\text { S } 01^{\circ} 48^{\prime} 03.0 " \\
\text { W } 46^{\circ} 58^{\prime} 33.2^{\prime \prime}\end{array}$ & $5 \mathrm{mt}$ \\
\hline$\ldots$ & Buiçú & Terapêutica & $\begin{array}{l}\text { Perto da aldeia } \\
\text { (campo) }\end{array}$ & $\begin{array}{l}\text { S } 01^{\circ} 47^{\prime} 56.7^{\prime \prime} \\
\text { W } 46^{\circ} 58^{\prime} 27.6^{\prime \prime}\end{array}$ & $\mathrm{Omt}$ \\
\hline & Cajueiro & Terapêutica & Perto da aldeia & $\begin{array}{l}\text { S } 01^{\circ} 47^{\prime} 24.8^{\prime \prime} \\
\text { W } 46^{\circ} 57^{\prime} 46.6 ”\end{array}$ & $1 \mathrm{mt}$ \\
\hline - & Camomila & Terapêutica & $\begin{array}{l}\text { Perto da aldeia } \\
\quad \text { (quintal) }\end{array}$ & $\begin{array}{l}\text { S 01⒋ } 48^{\prime} 03.1^{\prime \prime} \\
\text { W } 46^{\circ} 58^{\prime} 33.1^{\prime \prime}\end{array}$ & $1 \mathrm{mt}$ \\
\hline m & Canela & Terapêutica & Perto da aldeia & $\begin{array}{l}\text { S } 01^{\circ} 47^{\prime} 22.9^{\prime \prime} \\
\text { W } 46^{\circ} 58^{\prime} 00.1^{\prime \prime}\end{array}$ & $1 \mathrm{mt}$ \\
\hline - & Cedro & Terapêutica & $\begin{array}{c}\text { Perto da estra- } \\
\text { da/ramal }\end{array}$ & $\begin{array}{l}\text { S } 01^{\circ} 47^{\prime} 31.0^{\prime \prime} \\
\text { W } 46^{\circ} 57^{\prime} 50.0\end{array}$ & $1 \mathrm{mt}$ \\
\hline folthide CHiC & Chicória & Terapêutica & $\begin{array}{l}\text { Perto da aldeia } \\
\quad \text { (quintal) }\end{array}$ & $\begin{array}{l}\text { S } 01^{\circ} 47^{\prime} 22.4^{\prime \prime} \\
\text { W } 46^{\circ} 57^{\prime} 57,2^{\prime \prime}\end{array}$ & $3 \mathrm{mt}$ \\
\hline - & Ciqueira & Terapêutica & $\begin{array}{c}\text { Perto da estra- } \\
\text { da/ramal }\end{array}$ & $\begin{array}{l}\text { S } 01^{\circ} 47^{\prime} 31.1^{\prime \prime} \\
\text { W } 46^{\circ} 57^{\prime} 49.7^{\prime \prime}\end{array}$ & $\mathrm{Omt}$ \\
\hline
\end{tabular}


Ponte, Ribeiro, Santos \& Bentes: Uma Área de Pastagem

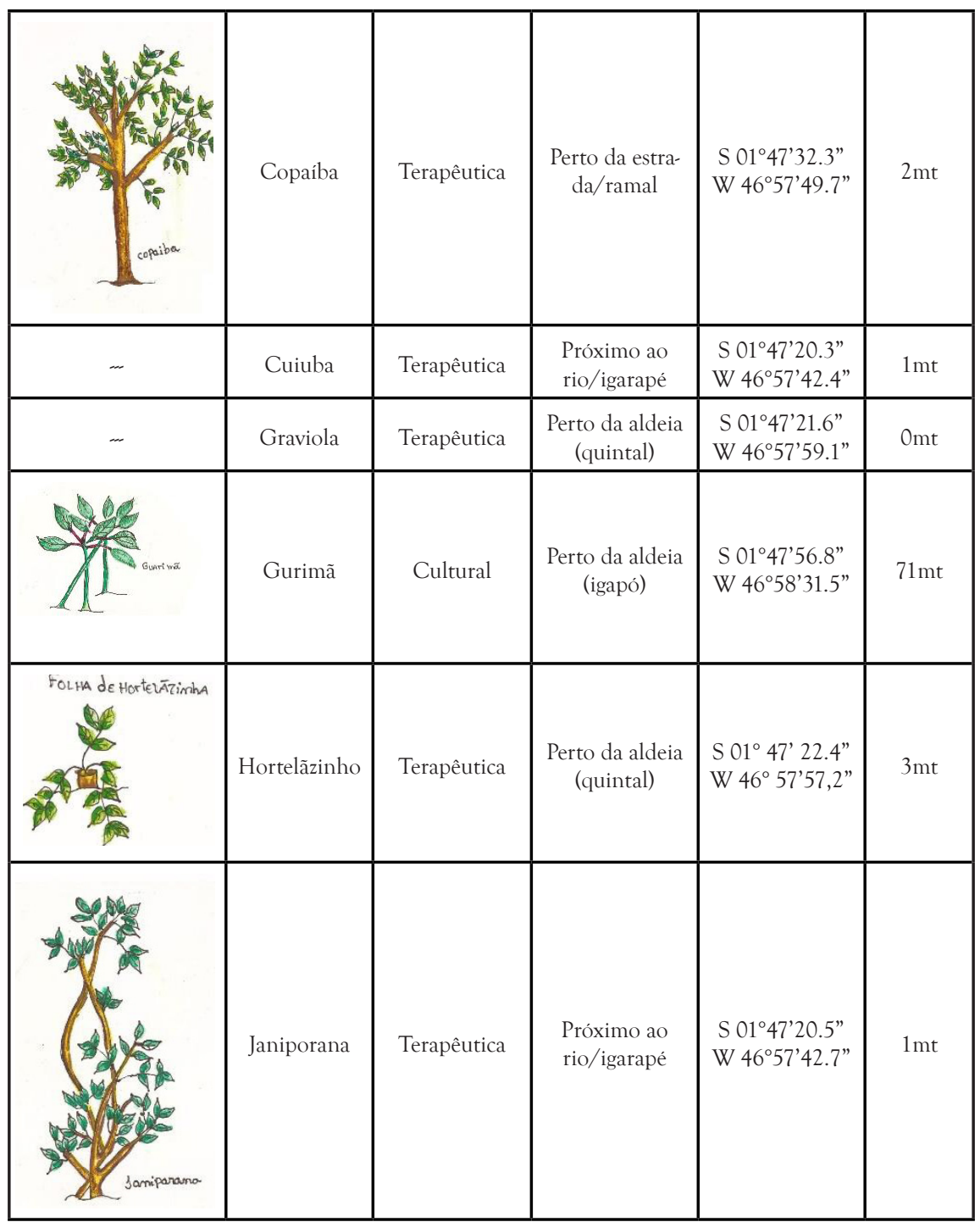




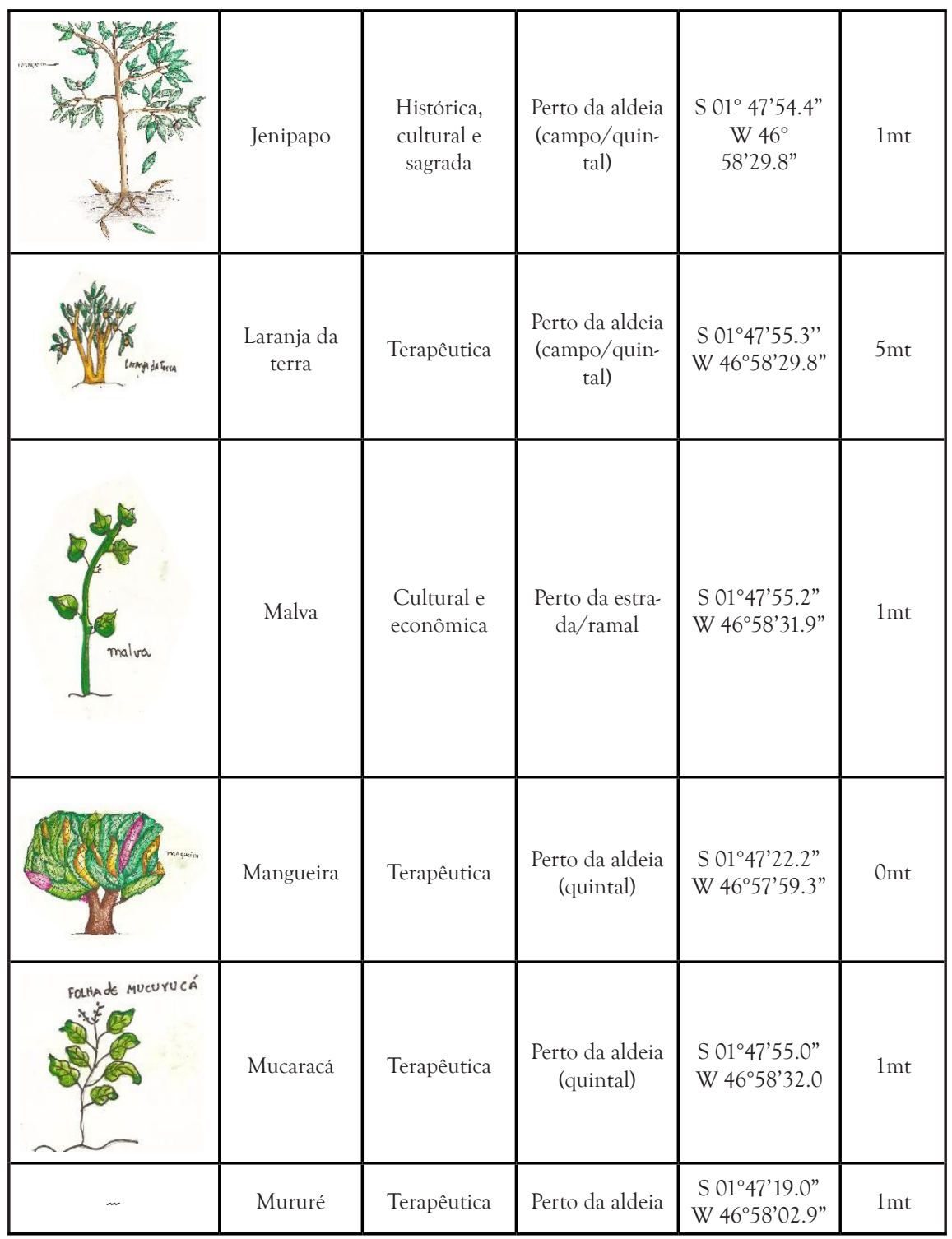


Ponte, Ribeiro, Santos \& Bentes: Uma Área de Pastagem

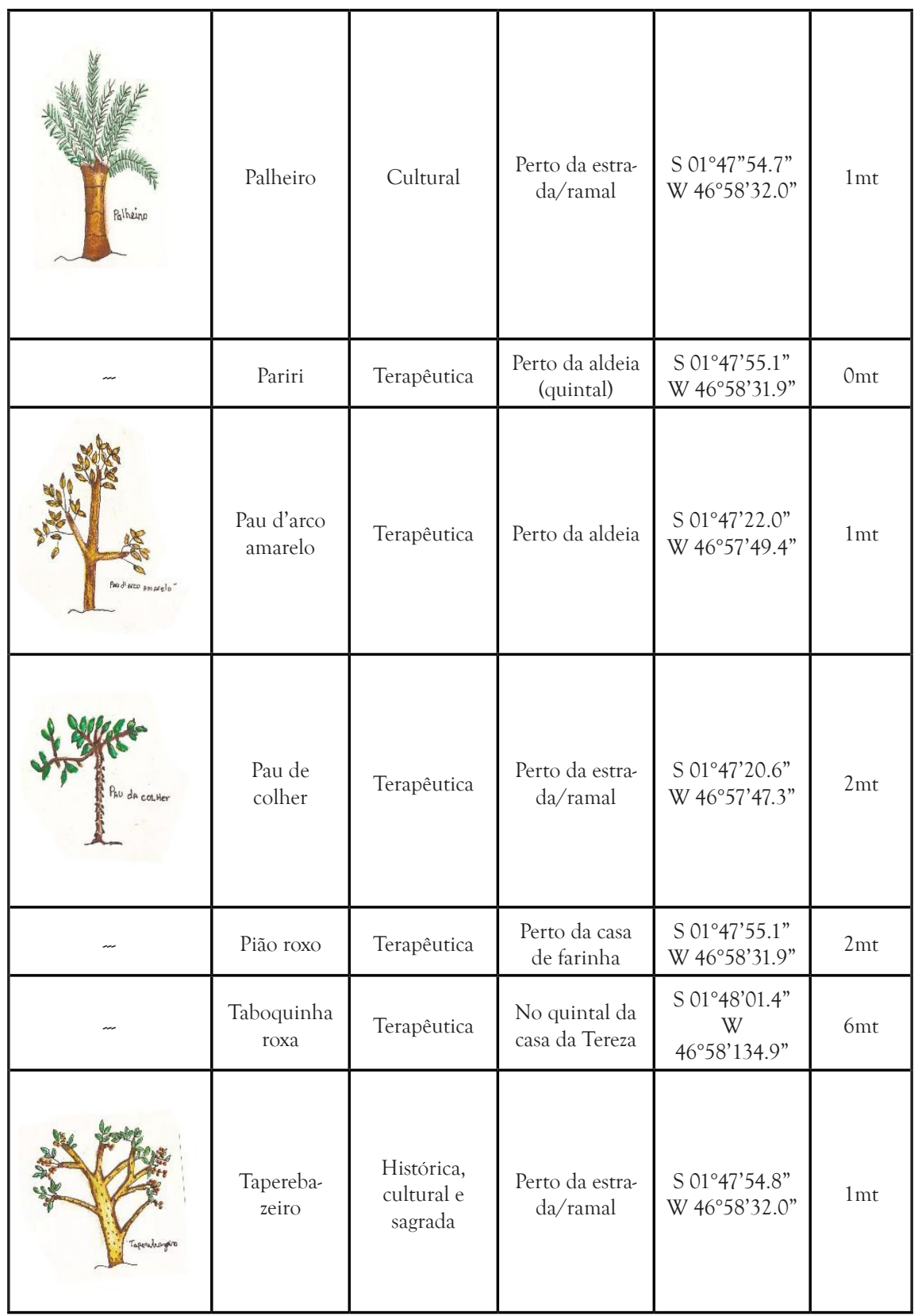




\begin{tabular}{|c|c|c|c|c|c|}
\hline & Tauari & $\begin{array}{l}\text { Histórica, } \\
\text { cultural e } \\
\text { sagrada }\end{array}$ & $\begin{array}{l}\text { Próximo ao } \\
\text { rio/igarapé }\end{array}$ & $\begin{array}{l}\text { S } 01^{\circ} 47^{\prime} 14.3^{\prime \prime} \\
\text { W } 46^{\circ} 57^{\prime} 55.2^{\prime \prime}\end{array}$ & $3 \mathrm{mt}$ \\
\hline- & Terramirina & Terapêutica & Perto da aldeia & $\begin{array}{l}S 01^{\circ} 47^{\prime} 55.2^{\prime \prime} \\
\text { W } 46^{\circ} 58^{\prime} 31.8\end{array}$ & $1 \mathrm{mt}$ \\
\hline folnade Vimd & Vindicá & Terapêutica & $\begin{array}{l}\text { Perto da aldeia } \\
\quad \text { (quintal) }\end{array}$ & $\begin{array}{l}\text { S } 01^{\circ} 48^{\prime} 02,9^{\prime \prime} \\
\text { W } 46^{\circ} 58^{\prime} 32,7^{\prime \prime}\end{array}$ & $1 \mathrm{mt}$ \\
\hline 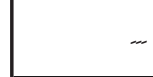 & Vic & Terapêutica & $\begin{array}{l}\text { Perto da aldeia } \\
\quad \text { (quintal) }\end{array}$ & $\begin{array}{l}\text { S } 01^{\circ} 47^{\prime} 22,4^{\prime \prime} \\
\text { W } 46^{\circ} 57^{\prime} 57,2^{\prime \prime}\end{array}$ & $3 \mathrm{mt}$ \\
\hline$\omega$ & Viki & Terapêutica & Perto da aldeia & $\begin{array}{l}\text { S } 01^{\circ} 47^{\prime} 31,8^{\prime \prime} \\
\text { W } 46^{\circ} 58^{\prime} 31,5^{\prime \prime}\end{array}$ & $10 \mathrm{mt}$ \\
\hline
\end{tabular}

Fonte: Dados coletados em campo e sistematizados pelos autores.

Abstract: In the article, we analyze the territorial dynamics among the Tenetehar-Tembé, their relations with health and the transmission of knowledge about the use of 'medicinal herbs'. Through ethnography and oral history, we find that the healing practices of the Tembé people delimit elements of resistance and re-existence, that trigger identity and of territoriality processes, especially when in tension with Western models of biomedicine implemented by the Health Subsystem Indigenous in the villages. Thus, we verified that the theme of health constitutes an important political resource of this group, given its strategic and justifying content to strengthen the defense of its territory and its culture.

Keywords: Knowledge, Health, Power, Territory, Territoriality, Tembé Indianity.

Recebido em abril de 2020. Aprovado em junho de 2020. 